\title{
Analisis Laju Pertumbuhan Dan Efektifitas Penerimaan Retrisubi Pengujian Kendaraan Bermotor Pada Dinas Perhubungan Kabupaten Malang
}

\author{
Angguliyah Rizqi Amaliyah ${ }^{1)}$ \\ Prodi Manajemen, Universitas Islam Raden Rahmat Malang \\ email: angguliyah.r@gmail.com
}

\begin{abstract}
Implementation of this research aims to analyze the rate of growth and effectiveness of the acceptance of the test retribution of motor vehicles (PKB) at the District Transportation Service Malang in 2015 to 2019. In this study techniques in collecting data IE primary data and secondary data. Based on the results of documentation, interviews and observations on the Transportation Service Department of Motor vehicle testing. Based on the results of research that has been done shows the level of growth of motor vehicle testing in Malang district from 2015 to 2019 with an average of 6.83\% (positive category). Percentage rate of growth in the matrix of potential retribution of motorised vehicle test is included in the prime category so that it becomes the mainstay sector for Malang Regency government. As well as belonging to the developing category because of its potential contribution to increased growth rate (positive). Calculation results at the level of effectiveness during the year 2015 to 2019 shows an average of 102.19\%. Percentage level of effectiveness demonstrated the performance of the district government of Malang in the Department of Transportation in receipt of the test retribution of motor vehicles, including the category is very effective on every duty and capable of management and managing the acceptance of the test retribution of motor vehicles.
\end{abstract}

Keywords: Growth Rate, Effectiveness, Motorized Vehicle Testing Levies

\begin{abstract}
Abstrak
Pelaksanaan penelitian ini bertujuan untuk menganalisis laju pertumbuhan dan efektivitas penerimaan retribusi pengujian kendaraan bermotor (PKB) Pada Dinas Perhubungan Kabupaten Malang pada tahun 2015 sampai 2019. Dalam penelitian ini Teknik dalam pengumpulan data yaitu data primer dan data sekunder. Berdasarkan hasil dokumentasi, wawancara, dan observasi pada Dinas Perhubungan bagian pengujian kendaraan bermotor. Berdasarkan hasil penelitian yang sudah dilakukan menunjukkan tingkatan laju pertumbuhan pengujian kendaraan bermotor di Kabupaten malang mulai 2015 sampai 2019 dengan rata-rata sebesar 6,83\% (kategori positif). Prosentase laju pertumbuhan pada matrik potensi retribusi pengujian kendaraaan bermotor masuk dalam kategori prima sehingga menjadi sektor andalan bagi Pemerintah Kabupaten Malang. Serta termasuk dalam kategori berkembang karena kontribusinya sangat potensial dengan tingkat pertumbuhan yang meningkat (positif). Hasil perhitungan pada tingkat efektivitas selama tahun 2015 sampai 2019 menunjukkan rata-rata sebesar $102,19 \%$. Prosentase tingkat efektifitas menunjukkan kinerja Pemerintahan Kabupaten Malang pada Dinas Perhubungan dalam penerimaan retribusi pengujian kendaraan bermotor termasuk kategori sangat efektif disetiap menjalankan tugas serta mampu memanajemen dan mengelola penerimaan retribusi pengujian kendaraan bermotor.
\end{abstract}

Kata Kunci : Laju Pertumbuhan, Efektifitas, Retribusi Pengujian Kendaraan Bermotor

\section{PENDAHULUAN}

Negara Indonesia adalah salah satu negara dengan menganut sistem otonomi daerah dalam pelaksanaan dan pengelolaan pemerintahanya. Suatu sistem yang memberikan kewenangan dan hak bagi Pemerintah daerah demi kepentingan warganya baik secara materil maupun non materil yang merupakan definisi sitem otonomi daerah. Sistem otonomi daerah dalam tujuanya selalu mempermudah dalam pemberian pelayanan, pengecekan/ pengontrolan, pantauan sumber dana alokasi (APBD) yang sudah digunakan. Otonomi daerah telah dijalankan oleh Pemerintah sejak tanggal 1 bulan Januari tahun 2001. Pemberian kewenanangan pada Pemerintahan daerahnya berguna untuk pelaksanaan pengelolaan potensi sumber daya yang ada untuk dapat meningkatkan kesejahteraan serta 
perekonomian masyarakat. Setiap daerah memperoleh kewajiban dan haknya untuk mengatur, mengurus rumah tangganya sendiri untuk meningkatkan efektifitas dan efisiensi penyelenggaraan pemerintahan serta pelayanan pada masyarakat.

Sesuai dengan Undang-undang No 22 tahun 1999 bahwa dengan menggunakan konsep desentralisasi diharapkan pemerintahan yang bersifat otoriter dan sentralistik dapat dihilangkan serta dapat mewujudkan proses demokratisasi yang mandiri. Otonomi daerah dan disentralisasi fiskal diatur pada UU nomor 2 (2015) atas perubahan ke dua UU nomor 23 (2014) tentang Pemerintah Daerah. Dalam pelaksanaan tugas Pemerintah, pembiayaan pembangunan atas tugas-tugas senantiasa membutuhkan sumber penerimaan yang bisa diandalkan. Demi penyelenggaraan secara luas, bertanggung jawab dan nyata dalam pelaksanaan otonomi daerah maka sangat membutuhkan kewenangan, kemampuan dalam pencarian dana yang sudah didukung baik antara pusat maupun daerah sesuai yang diatur dalam UU No 33 (2004). Serta dijelaskan bahwa sumber pendapatan asli daerah adalah dari retribusi daerah.

Retribusi daerah merupakan penarikan pemungutan yang harus dibayarkan atas perizinan /jasa yang sudah diberikan oleh pemerintahan daerahnya baik untuk individu maupun badan. UU no. 28 (2009) tentang pajak daerah dan retribusi daerah yaitu retribusi jasa umum, retribusi jasa usaha dan retribusi perizinan tertentu. Pelaksanaan pembagunan didaerah baik di Kabupaten maupun Kota selalu mengoptimalkan penerimaan sumber pendapatan yang berasal dari retribusi dan pajak daerah. Objek retribusi pengujian kendaraan bermotor merupakan salah satu sumber pendapatan Kabupaten Malang yang diharapkan bisa menjadi sumber dana pembiayaan dalam melaksanakan pemerintahan serta pembangunan daerah untuk meningkatkan kesejahteraan rakyat.

Peningkatan perkembangan pelaksanaan pembangunan daerah di Kabupaten Malang, salah satunya dapat dilihat melalui laju pertumbuhan dan efektivitas penerimaan retribusi pengujian kendaraan bermotor (PKB). Dengan demikian berdasarkan latar belakang diatas, peneliti ingin mengetahui bagaimana analisis laju pertumbuhan dan tingkat efektivitasnya. Dari hasil pencapaian realisasi pengujian kendaraan bermotor maka peneliti tertarik untuk melakukan penelitian dengan judul "Analisis Laju Pertumbuhan dan Efektifitas Penerimaan Retribusi Pengujian Kendaraan Bermotor Pada Dinas Perhubungan Kabupaten Malang"

\section{KAJIAN TEORI DAN PENGEMBANGAN HIPOTESA}

\section{A. RETRIBUSI DAERAH}

Retribusi daerah berdasarkan UU No 28 (2009) merupakan pemungutan yang dilakukan pemerintah daerah atas perizinan (pembayaran atas jasa) yang sudah diberikan oleh Pemerintahan daerah berguna bagi kepentingan individu maupun badan. Menurut Mahmudi (2009: 25) retribusi daerah merupakan pungutan yang dilakukan oleh pihak Pemerintah Daerah kepada wajib retribusi atas pemanfaatan jasa tertentu yang sudah tersedia, dan adanya imbalan (kontraprestasi) langsung yang bisa dinikmati oleh pembayar retribusi.

Menurut Josef K.R (2005: 171) retribusi daerah adalah pungutan daerah atas pembayaran pemakaian jasa pekerjaan, usaha yang dimiliki daerah yang disediakan untuk umum, jasa yang sudah disediakan bisa secara tidak langsung atau langsung. Menurut Boediono dalam buku Perpajakan Indonesia (2001: 14) menjelaskan bahwa retribusi merupakan pembayaran yang dilakukan oleh mereka yang menikmati jasa negara secara langsung. Jenis retribusi daerah oleh (Ahmad Yani, 2002 : 56) Diantaranya : 
1) Retribusi jasa umum merupakan retribusi jasa yang sudah diberikan dan disediakan oleh Pemerintahan Daerah yang berguna untuk kepentingan dan pemanfaatan umum yang dapat dinikmati baik pribadi maupun badan.

2) Retribusi jasa usaha merupakan retribusi jasa yang sudah diberikan oleh Pemerintahan Daerah yang memiliki tujuan komersial karena dalam sektor swasta bisa menyediakan.

3) Retribusi Perizinan tertentu merupakan kegiatan retribusi dalam pemberian perizinan baik individu maupun badan guna mengatur, membina, mengendalikan, dan mengawas atas penggunaan ruang, SDA, fasilitas, barang, yang sudah tersedia untuk umum, serta untuk melindungi dan melestarikan lingkungan.

\section{B. RETRIBUSI PENGUJIAN KENDARAAN BERMOTOR}

Berdasarkan Peraturan Daerah Kabupaten Malang Nomor 7 (2018) tentang Perubahan Ke-4 atas Peraturan Daerah Nomor 10 Tahun 2010 tentang Retribusi Jasa Umum, menjelaskan bahwa Pengujian kendaraan bermotor merupakan serangkaian kegiatan menguji dan memeriksa bagian kendaraan bermotor, kendaraan gandengan dan kereta tempelan sertakendaraan khusus guna memenuhi persyaratan teknis dan layak jalan. Pengujian berkala kendaraan bermotor dan kemudian uji berkala yaitu uji atas kendaraan bermotor yang dilakukan secara berkala terhadap setiap kendaraan bermotor, kereta gandengan, dan kereta tempelan, yang dioperasikan di jalan.

\section{LAJU PERTUMBUHAN}

Laju pertumbuhan menurut Halim, (2004 :163) menunjukkan kemampuan pemerintah daerah dalam mempertahankan, meningkatkan retribusi daerah yang dicapai dari period eke periode berikutnya. Diketahuinya laju pertumbuhan dari masing-masing jenis retribusi bisa digunakan sebagai kajian evaluasi potensi yang harus ditingkatkan. Rumus perhitungan untuk mengetahui laju pertumbuhan menurut Halim, 2004: 163 adalah sebagai berikut:

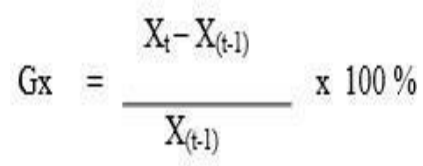

Keterangan:

Gx : Laju pertumbuhan RPKB

$\mathrm{X}_{\mathrm{t}} \quad$ : Realisasi penerimaan RPKB tahun tertentu

$\mathrm{X}_{(\mathrm{t}-1)} \quad$ : Realisasi penerimaan RPKB tahun sebelumnya

Adapun klasifikasi kriteria tingkat laju pertumbuhan melalui matrik potensi retribusi pengujian kendaraan bermotor:

\begin{tabular}{lll}
\hline \multirow{2}{*}{ Pertumbuhan } & \multicolumn{2}{c}{ Kontribusi } \\
& Potensial & Tidak \\
\cline { 2 - 3 } & & Potensial \\
\hline Positif & Prima & Berkembang \\
Negatif & Potensial & Terbelakang \\
\hline
\end{tabular}

Sumber: Haning dan Radianto, 2005 
Adapun tujuan perhitungan laju pertumbuhan retribusi pengujian kendaraan bermotor (PKB) yaitu untuk mengetahui laju pertumbuhan penerimaan retribusi PKB selama lima tahun yaitu mulai tahun 2015 sampai tahun 2019.

\section{RASIO EFEKTIVITAS}

Menurut Mardiasmo, (2004:4) menjelaskan pengertian efektivitas yang pada umumnya berkaitan dengan ukuran kemampuan dalam mencapai sasaran dan tujuan tertentu. Ukuran kemampuan yang dimaksud tergantung pada sasaran atau tujuan yang akan dicapai yang sudah ditetapkan.

Perbandingan masukan dan keluaran dalam berbagai jenis kegiatan hingga pencapaian tujuan yang sudah ditetapkan baik dari segi kuantitas maupun kualitas hasil kerja dalam batas waktu yang sudah ditargetkan menurut Ruchyat Kosasih dalam Agoes Sukirno (2000 :180). Suatu organisasi akan dinyatakan efektif apabila output yang dihasilkan dapat memenuhi tujuan yang diinginkan.

Tingkat efektivitas dari hasil uji kendaraan bermotor akan menggambarkan keadaan suatu kemampuan Pemerintahan Daerah dalam merealisasikan PAD yang sudah terancang dan dibandingkan dengan tujuan yang sudah tetapkan. Dari hasil perhitungan tingkat efetivitas apabila nilai memberikan hasil lebih tinggi maka akan menggambarkan bahwa daerah tersebut mampu dalam memanajerial pengelolaan retribusi. Dengan demikian Pemerintahan Daerah membutuhkan adanya perhitungan secara rinci dari besarnya pengeluaran biaya guna merealisasikan keseluruhan pendapatan yang sudah diterima hingga bisa diketahui apakah pendapatan dari pemungutuan tersebut dikatakan efisien atau tidak, menurut Faud (2016 :140).

Pengukuran kinerja oleh Pemerintah Daerah dalam penerimaan pendapatan daerah dapat mengukur menggunakan Rasio Efektivitas PAD menurut Mahmudi (2016 :141), yaitu dengan membandingkan realisasi penerimaan dengan target penerimaan retribusi $\mathrm{PKB}$. Berikut rumus dalam perhitungan tingat efektivitas:

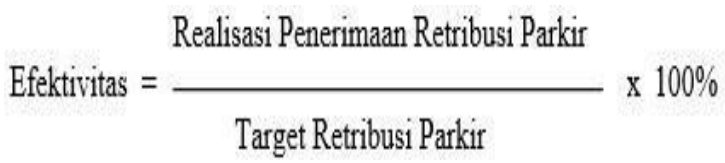

Adapun klasifikasi kriteria nilai efektifitas penerimaan retribusi pengujian kendaraan bermotor:

\begin{tabular}{l|l}
\hline Sangat Efektif & $>100 \%$ \\
Efektif & $100 \%$ \\
Cukup Efektif & $90 \%-99 \%$ \\
Kurang Efektif & $75 \%-89 \%$ \\
Tidak Efektif & $<75 \%$ \\
\hline
\end{tabular}

Sumber : mahmudi,2016 hal 141 


\section{HIPOTESIS PENELITIAN}

Hipotesis yang dicari oleh peneliti yaitu analisis laju pertumbuhan dan efektifitas penerimaan retribusi pengujian kendaraan bermotor pada Dinas Perhubungan Kabupaten Malang.

\section{METODE PENELITIAN}

\section{Objek Penelitian}

Objek penelitian ini dilaksanakan pada Dinas Perhubungan Kabupaten Malang yaitu pada bagian pengujian kendaraan bermotor.

\section{Tempat dan Waktu Penelitan}

Pelaksanaan penelitian dilakukan pada Dinas Perhubungan Kabupaten Malang Jl. Raya Talangagung, pada hari Senin tanggal 3 Juli 2020.

\section{Jenis Penelitian}

Dari penelitian yang sudah dilakukan, maka peneliti menggunakan jenis metode penelitian kualitatif. Peneliti menggunakan metode ini untuk mengetahui kondisi objek tersebut secara alamiah, peneliti sebagau instrument kunci. Menurut Creswell dalam Sugiyono,2017 halaman 206, menjelaskan bahwa dalam penelitian kualitatif merupakan eksplorasi pemahan makna perilaku baik secara kelompok maupun individu dengan mendeskripsikan suatu permasalahan social maupun kemanusiaan.

Proses dalam penelitian yang mencakup dari pertanyaan yang dibuat dengan prosedur sementara, pengumpulan data pendukung, menganalisis dengan cara induktif, tema yang dibangun dari data parsial, kemudian menginterpretasi tafsiran makna data. Dengan mengakhiri laporan yang dibuat dalam struktur yang fleksibel.

\section{Sumber Data}

Sumber data pada penelitian ini adalah sumber data primer dan sekunder. Menurut Sugiyono $(2017 ; 137)$, sumber data primer merupakan pemberian data penelitian kepada pengumpul data secara langsung. Sumber data sekunder merupakan perolehan data penelitian dari literatur, buku-buku, serta dokumen perusahan yang sudah dibaca peneliti. Sumber data yang digunakan peneliti adalah menggunakan data sekunder yang berupa laporan target dan realisasi penerimaan retribusi PKB pada Dinas Perhubungan Kabupaten Malang.

\section{Teknik Pengumpulan Data}

Peneliti menggunakan teknik pengumpulan data yang diambil melalui teknik wawancara dan dokumentasi.

\section{Teknik Analisis Data}

Sugiyono (2017: 238) menjelaskan Teknik analisis data yaitu suatu proses pencarian data dan disusun secara sistematis dengan memperolehnya melalui sistem wawancara, catatan lapangan, pendokumentasian, menggunakan metode pengorganisasian data pada kategori, penjabaran pada unit, pelaksanaan sintesa, penyusunan pada pola, pemilihan yang berguna dan yang perlu dipelajari, serta pembuatan analisis kesimpulan yang dapat dipahami baik individu maupun umum.

Dari hasil penelitian, Teknik analisis data yang digunakan peneliti yaitu menggunakan analisis desktiptif (pengambilan hasil perhitungan dari retribusi PKB yang diterima mulai tahun 2015 sampai 2019. Dari hasil tersebut akan dihitung laju pertumbuhan dari tahun yang ditentukan dibandingkan tahun sebelumnya selama lima tahun terakhir. Kemudian dari data penerimaan retribusi pengujian kendaraan bermotor akan dihitung rasio efektivitas selama lima tahun terakhir mulai tahun 2015 sampai 2019. 


\section{HASIL DAN PEMBAHASAN}

Berdasarkan hasil penelitian ini, penulis menganalis laju pertumbuhan dan efektivitas penerimaan retribusi PKB Dinas Perhubungan Kabupaten Malang mulai tahun 2015 sampai tahun 2019.

Analisis Laju Pertumbuhan

Analisis laju pertumbuhan retribusi pengujian kendaraan bermotor digunakan untuk mengetahui bagaimana laju pertumbuhan penerimaanya mulai tahun 2015 sampai 2019 apakah memiliki hasil negative atau positif. Berikut merupakan hasil perhitungan laju pertumbuhan penerimaan retribusi pengujian kendaraan bermotor dari tahun 2015 sampai 2019.

Tabel 1 Laju Pertumbuhan Retribusi PKB Tahun 2015-2019

\begin{tabular}{cccc}
\hline Tahun & $\begin{array}{c}\mathrm{X}_{\mathrm{t}} \\
(\mathrm{Rp})\end{array}$ & $\begin{array}{c}\mathrm{X}_{\mathrm{t}-1} \\
(\mathrm{Rp})\end{array}$ & $\begin{array}{c}\mathrm{G}_{\mathrm{x}} \\
(\%)\end{array}$ \\
\hline 2015 & 2.533 .800 .000 & 2.665 .260 .000 & 5,18 \\
\hline 2016 & 2.665 .260 .000 & 2.811 .640 .000 & 5,49 \\
\hline 2017 & 2.811 .640 .000 & 2.873 .180 .000 & 2,18 \\
\hline 2018 & 2.873 .180 .000 & 2.846 .490 .000 & $-0,93$ \\
\hline 2019 & 2.846 .490 .000 & 3.479 .160 .000 & 22,23 \\
\hline
\end{tabular}

Sumber: Data Dioleh, Dishub Kab. Malang 2020

Berdasarkan tabel 1 diatas, hasil menunjukkan retribusi PKB Kabupaten Malang selama tahun 2015 sampai 2019 menunjukkan rata-rata pertumbuhan yang positif dengan nilai sebesar 6,83\%. Prosentase tersebut menunjukkan Kabupaten Malang dalam penerimaan retribusi PKB mengalami peningkatan selama lima tahun terakhir. Berdasarkan matrik potensi retribusi pengujian kendaraaan bermotor masuk dalam kategori prima sehingga menjadi sektor andalan bagi Pemerintah Kabupaten Malang. Serta termasuk dalam kategori berkembang karena kontribusinya sangat potensial dengan tingkat pertumbuhan yang meningkat (positif). Hasil penelitian rata-rata laju pertumbuhan di Kabupaten Malang dengan menunjukkan pertumbuhan yang positif berbeda dengan hasil penelitian Magdalena (2019) yang menunjukkan hasil pertumbuhan yang negatif.

Pada tahun 2014 menuju tahun 2015 laju pertumbuhan menunjukkan hasil sebesar 5,18\% dengan katerangan positif. Pada tahun 2015 menuju tahun 2016 laju pertumbuhan menunjukkan hasil sebesar 5,49\% dengan keterangan positif. Pada tahun 2016 menuju tahun 2017 laju pertumbuhan menunjukkan hasil sebesar 2,18\% dengan keterangan positif. Pada tahun 2017 menuju tahun 2018 laju pertumbuhan menunjukkan hasil sebesar $-0,930 \%$ dengan keterangan negatif. Pada tahun 2018 menuju tahun 2019 laju pertumbuhan menunjukkan hasil sebesar 22,23 dengan keterangan positif. Dari hasil laju pertumbuhan mulai tahun 2015 sampai 2019 yang menunjukkan hasil negatif yaitu di tahun 2017 menuju tahun 2018. Hal ini menujukkan hanya tahun 2018 matrik potensi laju pertumbuhan dalam kategori terbelakang dan tidak menjadi sektor andalan oleh Pemerintah Kabupaten Malang. Dan termasuk dalam kategori terbelakang karena kontribusinya tidak potensial dengan tingkat pertumbuhan yang menurun atau negatif. Analisis Efektivitas

Analisis Efektifitas yang digunakan dalam mengukur kinerja Pemerintah Kabupaten Malang pada Dinas Perhubungan dalam merealisasikan penerimaan retribusi pengujian kendaraan bermotor dengan target yang sudah ditentukan. Berikut merupakan hasil tingkat efektivitas dari penelitian yang sudah dilakukan selama tahun 2015 sampai 2019 sebagai berikut: 
Tabel 2 Efektivitas Penerimaan Retribusi PKB Tahun 2015 -2019

\begin{tabular}{|c|c|c|c|}
\hline Tahun & $\begin{array}{c}\text { Target } \\
(\mathrm{Rp})\end{array}$ & $\begin{array}{c}\text { Realisasi } \\
(\mathrm{Rp})\end{array}$ & $\begin{array}{c}\text { Efektifitas } \\
(\%)\end{array}$ \\
\hline 2015 & 2.515 .560 .000 & 2.665 .260 .000 & 105,95 \\
\hline 2016 & 2.799 .140 .000 & 2.811 .640 .000 & 100,45 \\
\hline 2017 & 2.869 .120 .000 & 2.873 .180 .000 & 100,14 \\
\hline 2018 & 2.789 .000 .000 & 2.846 .490 .000 & 102,06 \\
\hline 2019 & 3.400 .000 .000 & 3.479 .160 .000 & 102,33 \\
\hline
\end{tabular}

Sumber: Data Dioleh, Dishub Kab. Malang 2020

Berdasarkan tabel 2 diatas, hasil menunjukkan prosentase rata -rata tingkat efektifitas penerimaan retribusi pengujian kendaraan bermotor mulai tahun 2015 sampai 2019 sebesar $102,19 \%$. Nilai tersebut menunjukkan kinerja Pemerintahan Kabupaten Malang pada Dinas Perhubungan dalam penerimaan retribusi pengujian kendaraan bermotor dalam kategori sangat efektif dalam menjalankan tugas serta mampu dalam memanajemen dan mengelola penerimaan retribusi pengujian kendaraan bermotor. Hasil penelitian ini dengan kategori sangat efektif menunjukkan perbedaan dengan penelitian yang dilakukan oleh Purweni Widyaningrum (2019) yang menunjukkan hasil efektifitas dengan kategori cukup efektif (pencapaian kurang dari 100\%). Serta menunjukkan hasil penelitian sama yaitu hasil sangat efektif, penelitian dari Zeliana (2018).

Rasio efektivitas penerimaan retribusi pengujian kendaraan bermotor di tahun 2015 menunjukkan prosentase sebesar 105,95\% dan termasuk dalam kategori sangat efektif. Pada tahun 2016 prosentase tingkat efektifitas sebesar 100,45\%. Meski dalam kondisi menurun sebesar 5,5\% dengan demikian masih termasuk dalam kategori sangat efektif. Pada tahun 2017 prosentase tingkat efektifitas sebesar 100,14\% menunjukkan penurunan sebesar $0,31 \%$, dari tahun sebelumnya, dengan demikian masih termasuk dalam kategori sangat efektif karena lebih dari 100\%. Pada tahun 2018 prosentase tingkat efektifitas sebesar $102,06 \%$ menunjukkan peningkatan $1,92 \%$ dari tahun sebelumnya, dengan demikian kategori termasuk sangat efektif pada tahun tersebut. Pada tahun 2019 prosentase tingkat efektifitas sebesar $102,33 \%$ menunjukkan peningkatan sebesar $0,27 \%$ dari tahun sebelumnya, dengan demikian kategori termasuk sangat efektif di tahun 2019.

\section{KESIMPULAN DAN SARAN}

\section{A. KESIMPULAN}

Berdasarkan hasil penelitian yang dilakukan pada Dinas Perhubungan Kabupaten Malang tentang analisis laju pertumbuhan dan efektifitas penerimaan retribusi pengujian kendaraan bermotor selama lima tahun terakhir yaitu tahun 2015 - 2019 mengalami fluktuatif sehingga diupayakan bagi Pemerintah Kabupaten Malang untuk tetap meningkatkan penerimaan retribusi pengujian kendaraan bermotor untuk tahuntahun berikutnya.

Berdasarkan hasil dari laju pertumbuhan penerimaan retribusi pengujian kendaraan bermotor di Kabupaten Malang menunjukkan prosentase sebesar 6,83\% . Prosentase tersebut menunjukkan nilai yang positif. Matrik potensi retribusi pengujian kendaraaan bermotor masuk dalam kategori prima, hal ini menunjukkan retribusi pengujian kendaraan bermotor menjadikan sektor andalan bagi Pemerintah Kabupaten Malang.

Serta termasuk dalam kategori berkembang karena kontribusinya sangat potensial dengan tingkat pertumbuhan yang meningkat (positif).

Berdasarkan hasil dari efektifitas penerimaan retribusi pengujian kendaraan 
bermotor menunjukkan rata-rata prosentase sebesar 102,19\% selama tahun 2015 sampai 2019. Nilai prosentase tersebut menujukkan kinerja Pemerintahan Kabupaten Malang pada Dinas Perhubungan dalam penerimaan retribusi pengujian kendaraan bermotor dalam kategori sangat efektif dalam menjalankan tugas serta mampu dalam memanajemen dan mengelola penerimaan retribusi pengujian kendaraan bermotor.

\section{B. SARAN}

Dari hasil penelitian yang sudah dilakukan, maka saran bagi Dinas Perhubungan Kabupaten Malang dalam meningkatkan penerimaan retribusi pengujian kendaraan bermotor adalah sebagai berikut:

1. Perlu adanya perbaikan dari segi sumber daya manusia dalam melaksanakan pekerjaanya guna meningkatkan penerimaan retribusi pengujian kendaraan bermotor untuk tahun berikutnya.

2. Perlu menambahkan pos-pos pelayanan pengujian kendaraan bermotor yang bisa lebih mudah untuk dijangkau oleh masyarakat, terutama masyarakat pelosok Kabupaten Malang.

3. Memperkuat proses pengawasan, dan proses pemungutan retribusi pengujian kendaraan bermotor.

\section{DAFTAR PUSTAKA}

Agoes, Sukirno. (2000). Auditing. Edisi kedua. Fakultas Ekonomi. Universitas Indonesia. Jilid I. Jakarta

Ahmad, Yani. (2002). Hubungan Keuangan antara Pemerintah Pusat

Boediono. (2001). Perpajakan Indonesia.

Faud, M. Ramli. (2016). Analisis Keuangan Pemerintah daerah. Bogor: Ghalia Indonesia.

Halim, Abdul. (2004). Manajemen Keuangan Daerah. Edisi Revisi. UPP AMP YKPN, Yogjakarta.

Halim, Abdul. (20017). Akuntansi Keuangan DaerahI. Jakarta: Salemba Empat.

Kaho, Josef Riwu. (2005). Prospek Otonomi Daerah di Negara Republik Indonesia Faktorfaktor yang mempengaruhi Penyelenggaraan Otonomi Daerah. Jakarta: PT. Raja Grafindo Persada.

Magdalena, Silawati. (2019). Analisis Potensi, Efektifitas dan Efisiensi Retribusi Terminal Pada Dinas Perhubungan Kabupaten Sikka.Junal Projemen: UNIPA Maumere

Mahmudi. (2015). Manajemen Kinerja Sektor Publik. Edisi kedua. Yogyakarta: UPP STIM YKPN.

Mahmudi. (2016). Analisis Laporan Keuangan Pemerintah Daerah. Yogyakarta: UPP STIM YKPN.

Mardiasmo. (2004). Akuntansi Sektor Publik. Penerbit: Andi. Yogyakarta:

Pertaruran Daerah Kabupaten Malang Nomor 7 Tahun, (2018).

Perubahan ke-empat atas Peraturan Daerah Nomor 10 Tahun 2010.

Safitri, Zeliana. (2018). Analisis laju pertumbuhan dan efektifitas retribusi daerah di Badan Keuangan Daerah Kabupaten Tanah Data. IAIN Batusangkar

Sugiyono. (2017). Metode Penelitian Kuantitatif, Kualitatif, dan R\&D. Bandung : Alfabeta. Undang-Undang Nomor 28 (2019). Pajak Daerah dan Retribusi Daerah. Jakarta: RI Undang-Undang Nomor 22 Tahun 1999. Pemerintahan Daerah. Jakarta: RI Undang-Undang Nomor 2 Tahun 2015. Penetapan Peraturan Pemerintah. Jakarta: RI

Widhianingrum, Purweni. (2019). Analisis efektifitas penerimaan retribusi pengujian kendaraan bermotor di Kabupaten Ponorogo. Jurnal Akuntansi, Inventory Vol. 3 No 2. Oktober 2019 